\title{
Biochemical assessment of pancreatic disease in human immunodeficiency virus infected men
}

\author{
M R Hancock, N A Smith, D A Hawkins, B Gazzard, S G Ball
}

\begin{abstract}
Aim-To determine the usefulness of measuring amylase activity as an indicator of pancreatic disease in human immunodeficiency virus (HIV) positive patients. Methods-A prospective study of 129 ambulant HIV positive males. Total amylase, pancreatic amylase, and lipase activities were assayed using commercial test kits on an automated analyser. Samples with raised amylase were examined for the presence of macroamylasaemia using cellulose acetate electrophoresis.

Results-Thirty six (28\%) of the subjects had raised total amylase activities compared with healthy, age matched blood donors. However, almost half of these were because of an increase of the salivary fraction. Four subjects were found to have macroamylasaemia. Pancreatic amylase and lipase assays, more specific indicators of pancreatic disease, produced significantly fewer abnormal results. There was no association between abdominal symptoms and elevated enzyme levels.

Conclusions-Total amylase is a poor indicator of pancreatic disease in HIV infected outpatients. Specific assays for pancreatic amylase offer advantages over the traditional total amylase assay. The lipase assay produced the least number of abnormal results and its use could improve the biochemical identification of patients with possible pancreatic disease and allow a more selective investigation of these cases.

(F Clin Pathol 1997;50:674-676)
\end{abstract}

Keywords: amylase; lipase; human immunodeficiency virus

A high incidence of pancreatic involvement has been observed postmortem in human immunodeficiency virus (HIV) infected patients. In a review of a previously reported series, evidence of pancreatic disease was seen in 254 of 749 cases where the pancreas was examined histologically. ${ }^{1}$

Possible causes of pancreatic disease include

Chelsea and

Westminster Hospital, 369 Fulham Road, London SW10 9NH, UK

Correspondence to: Dr Hancock.

Accepted for publication 13 May 1997 idine and didanosine for HIV disease. Monitoring HIV infected patients for early signs of pancreatic involvement, particularly where drugs associated with pancreatic toxicity are being administered, is desirable.
The use of simple biochemical tests to monitor for pancreatic involvement are preferable to the use of more invasive or expensive tests such as endoscopic retrograde cholangiopancreatography and fast contrast enhanced computed tomography. Traditionally, amylase is used as the biochemical marker of pancreatitis; however, the availability of computed tomography has shown that up to $19 \%$ of patients with acute pancreatitis have serum amylase within the reference range ${ }^{2}$ and it is well recognised that amylase is raised in a variety of nonpancreatic diseases. $^{3}$

The reported incidence of hyperamylasaemia in HIV infected individuals depends on the population selected, varying from hyperamylasaemia without any other evidence of pancreatitis in $8 \%$ of patients being enrolled in a treatment study ${ }^{4}$ to $63 \%$ of patients on high dose didanosine. ${ }^{5}$ In one retrospective study of AIDS patients, hyperamylasaemia was present in $54 \%$ of those in whom amylase was measured; however, this was attributed to salivary amylase in a third of the cases. Pancreatitis was diagnosed in $31 \%$ of patients, although the disease tended to be mild. ${ }^{6}$

One reason for concern is that a number of the drugs used in HIV related treatment are recognised as potential causes of pancreatitis. In particular, treatment with pentamidine and didanosine and, less commonly, zalcitabine and trimethoprim-sulphamethoxazole are associated with pancreatitis.

In a study of children receiving didanosine, asymptomatic hyperamylasaemia occurred in $37 \%$ of patients. Investigation of some of these patients revealed salivary macroamylasaemia. ${ }^{8}$ Macroamylasaemia appears to occur relatively frequently in HIV infected patients, it has been suggested that the increase in immunoglobulin associated with HIV infection may predispose to macroamylase formation. ${ }^{9}$

\section{Materials and methods}

SERUM SAMPLES

Serum samples and brief clinical details were obtained from 129 consecutive HIV positive male patients attending outpatient clinics. Patients on clinical trials involving placebo controlled didanosine were excluded unless they were on open label drug. Patients were aged between 23 and 61 years (mean 35). One had a previous history of pancreatitis. For our reference population we used 52 male blood donors aged under 50 years.

\section{REAGENTS}

Samples were assayed on a Hitachi 911 autoanalyser (Boehringer Mannheim GmbH, 
Table 1 Enzyme activities in 52 male blood donors

\begin{tabular}{lll}
\hline & Mean (SD) IU/l & $\begin{array}{l}\text { Upper reference } \\
\text { limit }\end{array}$ \\
\hline Total amylase & $53(16)$ & 85 \\
Pancreatic amylase & $25(10)$ & 45 \\
Salivary amylase & $28(6)$ & 40 \\
Lipase & $32(16)$ & 64 \\
\hline
\end{tabular}

Mannheim, Germany) using the following reagents: $\alpha$ amylase EPS test (Boehringer Mannheim) for the measurement of total amylase. This uses a protected para nitrophenol substrate. Pancreatic $\alpha$ amylase EPS test (Boehringer Mannheim) for the measurement of pancreatic amylase after immunoinhibition of salivary amylase. Lipase-PS test (Sigma Diagnostics, St Louis, Missouri, USA) for the measurement of lipase using 1,2-diglyceride as a substrate in the presence of colipase and deoxycholate as activators. Macroamylasaemia was investigated using cellulose acetate electrophoresis. ${ }^{10}$

\section{Results}

Reference ranges were established for the assays (see table 1).

No patients were thought to have clinical pancreatitis but on direct questioning 43 patents $(33 \%)$ admitted to some degree of abdominal pain. There was no correlation between the presence or degree of abdominal pain and any of the parameters measured. One patient had a past history of pancreatitis but had no clinical or biochemical evidence of pancreatitis on this occasion.

Biochemical evidence suggestive of pancreatic disease was defined as the combined elevations of both pancreatic amylase and lipase. Nine such patients were identified (table 2).
The total amylase assay revealed hyperamylasaemia in 36 of the 129 patients (28\%). All patients with a total amylase activity above 100 IU/l were examined for the presence of macroamylasaemia. Four cases of macroamylasaemia were demonstrated and in two of these the amylase was of the pancreatic type.

Excluding the patients with macroamylasaemia, 13 hyperamylasaemic patients were found to have a raised salivary fraction with a normal pancreatic specific amylase. Overall, $35 \%$ of patients complained of dry mouth but there was no association between this and abnormal salivary amylase concentrations.

Both the pancreatic amylase and lipase assays produced significantly less abnormal results. Twenty seven patients (21\%) had raised pancreatic amylase, including two patients with macroamylasaemia and six patients whose total amylase was not raised. Only 15 patients (12\%) had raised lipase levels (fig 1).

We compared the nine patients who had biochemical evidence suggestive of pancreatic disease with the $96(74 \%)$ who had normal pancreatic amylase and lipase (including 15 with raised total amylase of salivary origin). There was no significant difference in age or the presence of abdominal pain between the two groups. Patients with raised pancreatic amylase and lipase had a significantly lower CD4 count (Mann-Whitney $p=0.036$ ) and alcohol intake (Mann-Whitney $p=0.019$ (table 3). There were no statistically significant associations between drug therapy and hyperamylasaemia.

\section{Discussion}

Despite reports indicating that the pancreas is affected frequently by HIV infection, assessment of pancreatic involvement is hampered by

Table 2 Findings in nine patients with biochemical evidence of pancreatic disease

\begin{tabular}{|c|c|c|c|c|c|c|c|}
\hline $\begin{array}{l}\text { Amylase } \\
\text { IU/l }\end{array}$ & $\begin{array}{l}\text { Pancreatic } \\
\text { amylase } \\
\text { IU/l }\end{array}$ & $\begin{array}{l}\text { Salivary } \\
\text { amylase } \\
\text { IUll }\end{array}$ & $\begin{array}{l}\text { Lipase } \\
\text { IUIll }\end{array}$ & Abdominal pain & Drugs & $C D 4\left(\times 10^{6} / l\right)$ & Alcohol units/week \\
\hline 226 & 137 & 89 & 86 & None & $\begin{array}{l}\text { Ethambutol } \\
\text { Clofazimine } \\
\text { Clarithromycin } \\
\text { Fluconazole } \\
\text { Megestrol } \\
\text { Trental } \\
\text { Dihydrocodeine } \\
\text { Pentamidine }\end{array}$ & 6 & 0 \\
\hline 204 & 172 & 32 & 490 & None & DDI & NA & NA \\
\hline 154 & 84 & 70 & 139 & Mild & Dapsone & 100 & 2 \\
\hline 137 & 90 & 47 & 93 & None & $\begin{array}{l}\text { Septrin } \\
\text { Ketoconazole }\end{array}$ & 52 & 2 \\
\hline 105 & 93 & 12 & 80 & Moderate & Septrin & 2 & 0 \\
\hline 104 & 71 & 33 & 92 & None & Nil & 366 & NA \\
\hline 88 & 74 & 14 & 65 & None & Septrin & 10 & 0 \\
\hline 81 & 59 & 22 & 189 & Moderate & $\begin{array}{l}\text { Acyclovir } \\
\text { Dapsone }\end{array}$ & 10 & 0 \\
\hline 75 & 60 & 15 & 83 & None & AZT Septrin & 165 & 0 \\
\hline
\end{tabular}

DDI, didanosine; NA, not available.

Table 3 Differences between patients with and without biochemical evidence of pancreatic disease

\begin{tabular}{|c|c|c|c|c|c|}
\hline & Number & $\begin{array}{l}\text { Mean }(S D) \text { age } \\
\text { (years) }\end{array}$ & $\begin{array}{l}\text { Mean CD4 count } \\
\left(\times 10^{\circ} / l\right)\end{array}$ & $\begin{array}{l}\text { Mean alcohol intake } \\
\text { (units/week) }\end{array}$ & Abdominal pain \\
\hline $\begin{array}{l}\text { Normal lipase and pancreatic } \\
\text { amylase } \\
\text { Raised lipase and pancreatic }\end{array}$ & 96 & $34.4(0.7)$ & 203 (19) & $10.9(2.1)$ & $35 \%$ \\
\hline $\begin{array}{l}\text { amylase } \\
\text { p value (Mann-Whitney) }\end{array}$ & 9 & $\begin{array}{l}38.6(1.6) \\
\text { NS }\end{array}$ & $\begin{array}{l}89(45) \\
0.036\end{array}$ & $\begin{array}{l}0.6(0.4) \\
0.019\end{array}$ & $\begin{array}{l}38 \% \\
\text { NS }\end{array}$ \\
\hline
\end{tabular}




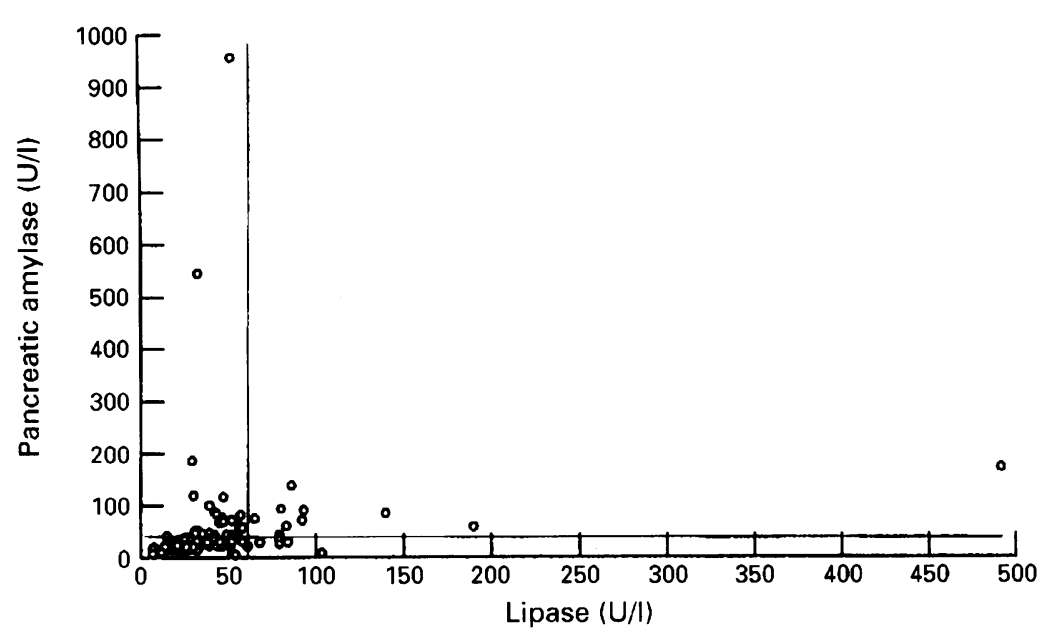

Figure 1 Lipase versus pancreatic amylase concentrations in 129 HIV positive male outpatients. The upper reference limit for each test is shown by a solid line.

the lack of investigations that are both simple and specific.

Our findings in HIV positive outpatients show a lack of correlation between the presence of abdominal pain and biochemical evidence of pancreatic disease. The use of total amylase alone to detect pancreatic abnormalities yields a high number of false positives: of 36 patients with raised total amylase only seven were finally considered to have possible pancreatic disease. In addition, two patients who did have possible pancreatic disease did not have raised total amylase.

The reference method for differentiation of iso-amylases is electrophoresis. Unfortunately this method is time consuming and not convenient for high risk samples. The recent introduction of an immunoinhibition assay for pancreatic amylase allows automation. This method has been shown to correlate well with electrophoresis. ${ }^{11}$ Although increased concentrations are strongly suggestive of pancreatic involvement they may also occur in macroamylasaemia and glomerular dysfunction. Fewer abnormal results were found using this assay compared with total amylase $(27 v 36)$. However, in only nine of these 27 cases was lipase raised.

The assay of plasma lipase is often advocated as a better indicator of pancreatic disease than total amylase. ${ }^{12}$ Technical problems, including lack of specificity, have prevented its widespread use, but methods using clear substrates with added colipase appear to have overcome these difficulties and allowed automation of the assay. Lipase appears to be relatively specific for the pancreas, ${ }^{13}$ although raised concentrations have been reported in patients with nonpancreatic abdominal pain. ${ }^{14}$
Lipase activity was raised in 15 of our patients and only in six was this not accompanied by a raised pancreatic amylase.

It is our view that the assay of plasma lipase should be the first line test in the investigation of pancreatic function in HIV infection where there is no clinical evidence of acute pancreatitis. This strategy would be no more expensive than measuring total amylase and would identify a smaller cohort of individuals who might benefit from more rigourous assessment of pancreatic status.

\section{CONCLUSIONS}

It appears that the frequency with which total amylase is raised makes it a poor indicator of pancreatic disease in HIV infected outpatients. The more specific assay for pancreatic amylase improves diagnostic capability but renal disease and macroamylasaemia may still produce misleading results. The availability of improved lipase assays may reduce the number of patients identified as having possible pancreatic disease and allow more selective investigation of these cases.

1 Brivet FG, Naveau SH, Lemaigre GF, Dormont J Pancreatic lesions in HIV-infected patients [review]. Balliere's Clin Endocrinol Metab 1994;8:859-77.

2 Clavien P-A, Robert J, Meyer P, Borst F, Hauser H, Herrmann F, et al. Acute pancreatitis and normoamylasaemia. Not an uncommon combination. Ann Surg 1989;210 614-20.

3 Salt WB, Schenker S. Amylase-its clinical significance: a review of the literature. Medicine 1976;55:269-89.

4 Lambertus MW, Anderson RE. Hyperamylasemia in patients with human immunodeficiency virus infection patients with human immunodeficiency

5 Maxson CJ, Greenfield SM, Turner JL. Acute pancreatitis as a common complication of 2 ',3'-dideoxyinosine therapy in the acquired immunodeficiency syndrome. $A m \mathcal{F}$ Gastroenterol 1992;87:708-13.

6 Murthy UK, DeGregorio F, Oates RP, Blair DC. Hyperamylasemia in patients with the acquired immunodeficiency syndrome. Am $\mathcal{f}$ Gastroenterol 1992;87:332-6.

7 Ball SG. The chemical pathology of AIDS. Ann Clin Biochem 1994;31:401-9.

8 Butler KM, Venzon D, Henry N, Husson RN, Mueller BU, Balis FM, et al. Pancreatitis in human immunodeficiency virus-infected children receiving dideoxyinosine. Pediatric 1993;91:747-51

9 Greenberg RE, Bank S, Singer C. Macroamylasaemia in association with the acquired immunodeficiency syndrome. Postgrad Med f 1987;63:677-9.

10 Foo Y, Rosalki SB. Isoenzymes of $\alpha$ amylase. In Bergmeyer HA, ed. Methods of enzymatic analysis. 3rd edn, Vol. IV. Weinheim: Verlag Chemie, 1984:167-77.

11 Van Deun A, Cobbaert C, Van Orshoven A, Claeys G, Lissens W. Comparison of some recent methods for the differentiation of elevated serum amylase and the detection of macroamylasaemia. Ann Clin Biochem 1989;26:422-6.

12 Lott JA, Patel ST, Sawhney AK, Kazmierczak SC, Love JE. Assays of serum lipase: analytical and clinical considerations. Clin Chem 1986;32:1290-302.

13 Apple F, Benson P, Preese L, Eastep S, Bilodeau L, Heiler G. Lipase and pancreatic amylase activities in tissues and in patients with hyperamylasaemia. Am 7 Clin Pathol 1991;96: patients

14 Tetrault GA. Lipase activity in serum measured with Ektachem is often increased in nonpancreatic disorders. Clin Chem 1991;37:447-51. 